\title{
Patellar luxation and articular lesions in dogs: a retrospective: study research article
}

\author{
[Luxação de patela e lesões articulares em cães: estudo retrospectivo] \\ J.S. Lara ${ }^{1}$, E.G. L.Alves ${ }^{2}$, H.P. Oliveira ${ }^{3}$, J.A.C. Varón ${ }^{1 *}$, C.M.F. Rezende ${ }^{3}$ \\ ${ }^{1}$ Aluno de pós-Graduação - Universidade Federal de Minas Gerais - UFMG - Belo Horizonte, MG \\ ${ }^{2}$ Universidade de Uberaba - Uniube - Uberaba, MG \\ ${ }^{3}$ Universidade Federal de Minas Gerais - UFMG - Belo Horizonte, MG
}

\begin{abstract}
This study describes lesions that occur in the stifle joints of dogs with patellar luxation. These lesions are associated with the animal's age, body weight, and degree of luxation. The rate of redislocation was also evaluated. The patellar lesions found include articular cartilage erosion, subchondral bone exposure, a flattened or concave patellar surface, and enthesophytes. Extra-patellar lesions included synovitis, osteophytes, blunting of the trochlear groove, an absent trochlea, erosion of the condylar margins, capsule thickening, a long digital extensor tendon injury, cranial cruciate ligament rupture, and meniscal prolapse. Such lesions were frequently found in animals with Grade II or III luxation who were aged 24 months or more, and they were more severe in dogs weighing more than $15 \mathrm{~kg}$. Patellar luxation causes changes that favor articular degeneration and should be treated surgically. Conservative treatment relieves pain, but does not address tissue alterations.
\end{abstract}

Keywords: dog, luxation, patella, lesions, joint

\section{RESUMO}

O estudo descreve as lesões articulares em cães com luxação de patela. Elas foram associadas com a idade do animal, massa corporal e grau de luxação. Foi avaliada também a porcentagem de casos com recidiva. As lesões patelares observadas foram erosão da cartilagem articular, exposição óssea subcondral, superfície patelar achatada ou côncava e entesófitos. As lesões extra patelares incluíram sinovite, osteófitos, ausência do sulco troclear, erosão das bordas condilares, espessamento da cápsula, lesão do tendão do músculo extensor digital, ruptura do ligamento cruzado cranial e prolapso de menisco. As lesões foram encontradas com maior frequência em animais com luxação de Grau II ou III e idade de 24 meses ou mais, sendo mais graves em cães com massa corporal superior a $15 \mathrm{~kg}$. A luxação patelar ocasiona alterações que favorecem a degeneração articular e devem ser tratadas cirurgicamente. O tratamento conservativo alivia a dor, mas não corrige as alterações teciduais.

Palavras chaves: cão, luxação, patela, lesões, articulação

\section{INTRODUCTION}

Patellar luxation is a frequent occurrence in dogs and thus, represents a common finding in everyday veterinary trauma and orthopedic practice (Roush, 1993). Although the pathophysiology of congenital luxation has not yet been elucidated (L'Eplattenier e Montavon, 2002; Souza et al., 2010), this malady is not considered an independent stifle joint disease,

Recebido em 15 de junho de 2016

Aceito em 21 de outubro de 2016

*Autor para correspondência (corresponding author)

E-mail: jesikastro@hotmail.com but instead, is considered a consequence of complex skeletal abnormalities that alter limb alignment (Piermattei et al., 2006).

The incidence of severe articular lesions found during routine surgeries in small-, medium-, or large-breed dogs presenting with patellar luxation is high. In some cases, the patella injury is so serious that correction is not possible or prudent. In these instances, the only treatment option is prosthetic replacement. 
According to the literature (Piermattei et al., 2006), surgery might not be necessary in cases without clinical manifestations or when lameness is mild; however, even under such circumstances, the joint damage is irreversible.

Patellar luxation is a degenerative illness, and surgical treatment should be performed as early as possible and while clinical signs are mild or even before the appearance of clinical symptoms. The aims of this study were to perform a retrospective survey of the lesions found in the stifle joints of dogs with patellar luxation; to investigate the associations between these lesions and the animal's age, body weight, and degree of luxation; and to estimate the incidence of reluxation after surgical treatment.

\section{MATERIALS AND METHODS}

This was a retrospective study that assessed the clinical surgical records of dogs treated for patellar luxation from January 2000 to July 2010 at the Veterinary Hospital of the Federal University of Minas Gerais (FUMG) in Brazil. Data describing age, body weight, and the degree of patellar luxation at admission were collected for each animal. The animals were then categorized based on body weight $(\leq 5 \mathrm{~kg}, 5-15$ $\mathrm{kg}$, and $\geq 15 \mathrm{~kg}$ ), age ( $<12$ months, 12-24 months, and >24 months), and degree of luxation according to Putnam's (1968) classification as adapted by Singleton (1969). In addition, data relative to the intraoperative period were recorded, and this included the presence of stifle joint damage, classified as patellar or extrapatellar lesions, and the frequency of postoperative reluxation. The associations between patellar or extra-patellar lesions and the animal's age, body weight, and degree of luxation were investigated. Patellar lesions included the presence of cartilage erosion, the extent of the erosion (one-fourth, one-half, or the full patellar articular surface), the morphology of the patella (concave or flat), the exposure of subchondral bone, and the presence of enthesophytes. Extra-patellar lesions included the presence of erosion and subchondral bone exposure in the medial or lateral femoral condyles; the presence of osteophytes, synovitis, capsular thickening, or shallowing of the trochlea; and an absent or convex trochlear groove; cruciate ligament rupture, injury of the long digital extensor tendon, and the menisci.

The frequency of lesions in the stifle joint was subjected to descriptive analysis, and the rate of patellar reluxation was assessed by means of the chi-square test. The significance level set at $\mathrm{P}<0.05$.

\section{RESULTS}

A total of 252 luxated joints from 187 dogs were assessed, and 218 were in medial luxation, whereas 34 were in lateral luxation. Sixteen $(6.3 \%)$ were classified as Grade I, 109 (43.3\%) as Grade II, $49(19.4 \%)$ as Grade III (19.4\%), and $78(31.0 \%)$ as Grade IV.

The patellar lesions identified included cartilage erosion of one-fourth $(13.1 \%)$, one-half $(10.7 \%)$, or all $(2.0 \%)$ of the patella, exposure of subchondral bone $(3.2 \%)$, a flattened or concave patellar surface $(15.1 \%)$, (Fig. 1), the presence of enthesophytes $(9.5 \%)$, and lesions caused by the patella rubbing on the long digital extensor tendon (Fig. 2). Tables 1 and 2 show the lesions according to degree of dislocation, weight, and age.

One rare instance of resorption of the patella was diagnosed in a dog with Grade III luxation. Some remnants of the bone were found adhered to the patellar tendon, while the central area was soft and exhibited loss of bone and cartilage. A oneyear history of severe lameness with frequent non-weight-bearing and Grade II medial luxation in the contralateral limb existed. Resorption of the patella was treated with implantation of a polyhydroxybutyrate patellar prosthesis. 

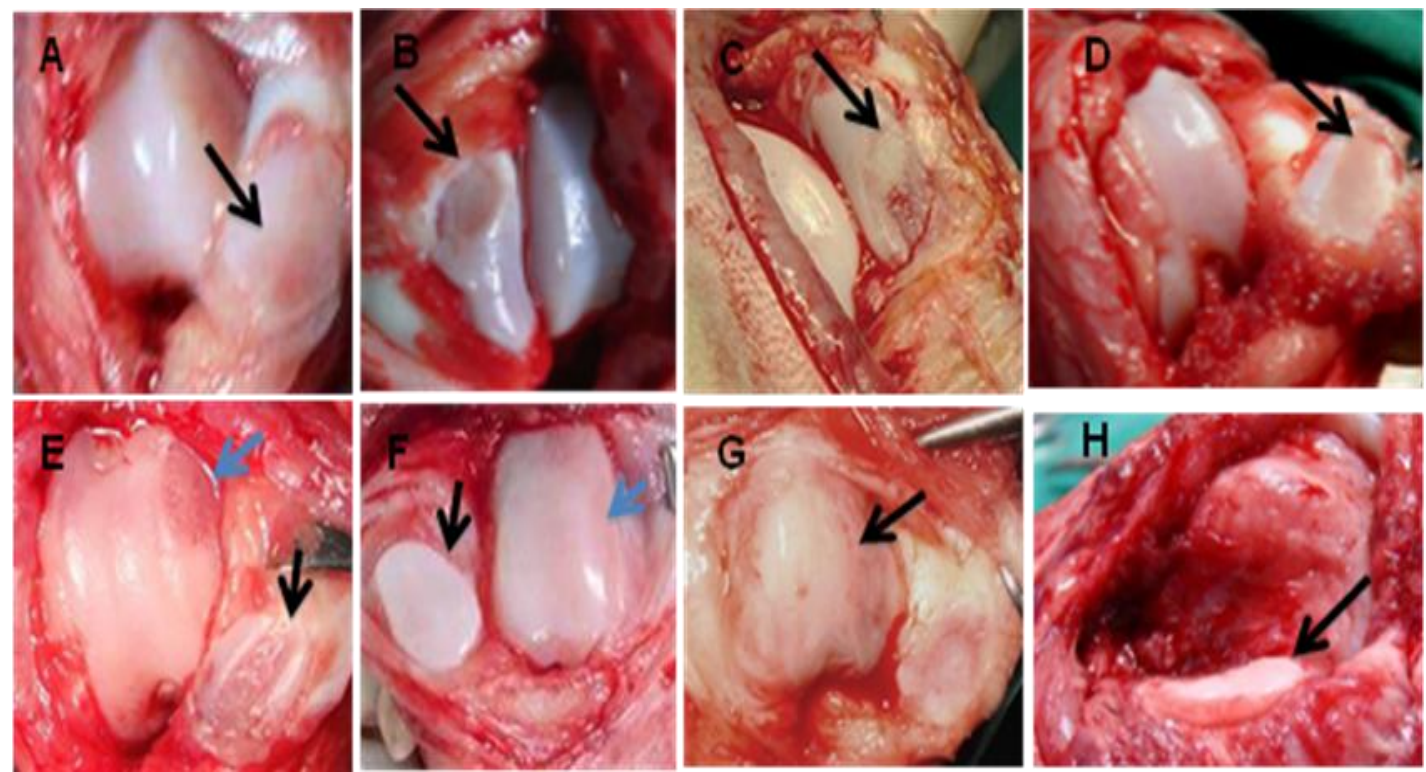

Figure 1. Photograph of the stifle joint of a dog subjected to surgery for patellar luxation. Notice the erosion of the patellar articular surface (black arrow). A) - Superficial erosion, B and C) - Severe erosion, D) Severe erosion in the whole extension of the patella. E) Erosion of the edge of the medial condyle and erosion of the patella with subchondral bone exposure (blue and black arrows). F) Notice the flattened patellar surface (black arrow) and shallow trochlear groove (blue arrow). G) Convex femoral trochlea (black arrow). H) Patella concave.
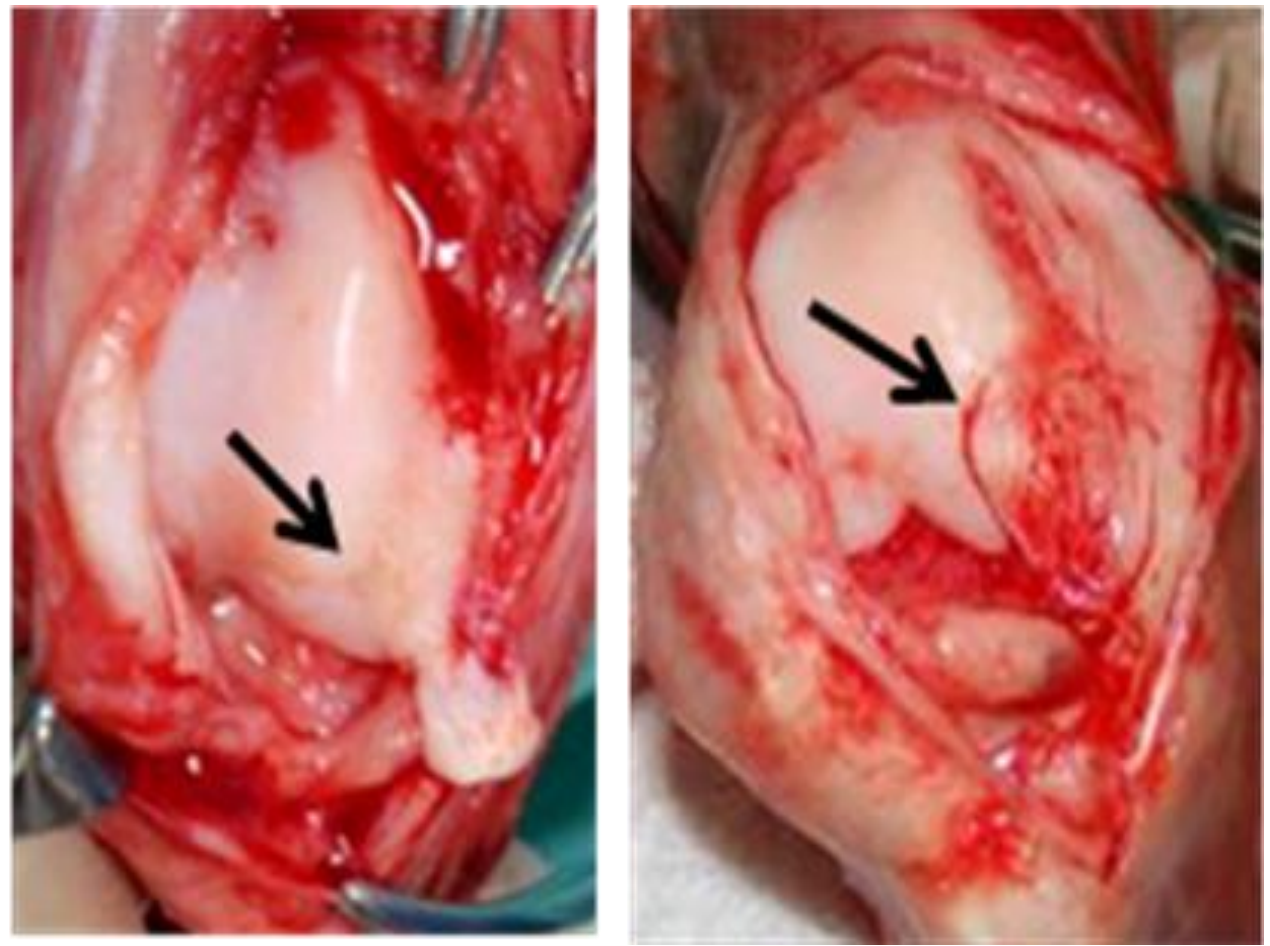

Figure 2. Photograph of the stifle joint of a dog subjected to surgery for patellar luxation. Notice the lesion by rubbing of the patella on the long digital extensor tendon (black arrow). 
Table 1. Estimated patellar lesions in dogs with patellar luxation treated at the Veterinary Hospital, FUMG, 2000-2010 according to the degree of luxation, body weight, and age

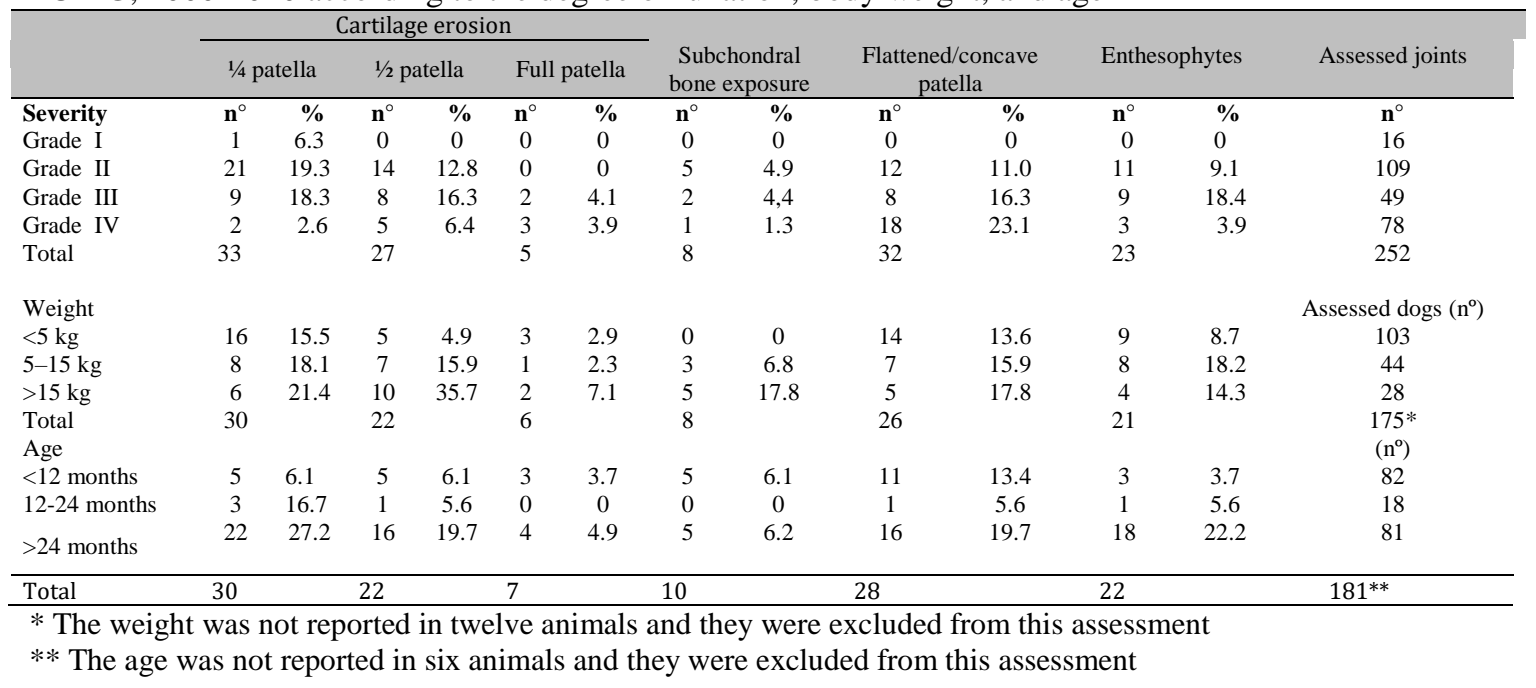

The frequency of cartilage erosion affecting onefourth or one-half of the patella accompanied by subchondral bone exposure was higher among those with Grade II or III luxation. Erosion of the full patellar surface occurred only in Grade III or IV luxation. Patellar lesions were frequently observed on the lateral surface in medial luxation, but were seen on the medial surface in lateral luxation. Anatomical changes of the patella, such as a flattened or concave surface, occurred primarily in Grade III or IV luxation, whereas enthesophytes were most frequently found in Grade III luxation. In animals older than 24 months, the lesions most frequently found were cartilage erosion affecting one-fourth or one-half of the patella, subchondral bone exposure, and the presence of enthesophytes. The frequency of anatomical changes of the patella (flattened or concave surface) was highest among those aged more than 24 months and lowest in those aged 12-24 months. The frequency of patellar lesions was proportionally higher among those animals weighing over $15 \mathrm{~kg}$ (Tab. 1).

Several extra-patellar lesions involving soft or hard tissue were found. On intraoperative assessment, $25.0 \%$ of the joints exhibited synovitis, $25.8 \%$ had periarticular osteophytes, $42.1 \%$ had shallow trochlear grooves, $13,1 \%$ had absent trochleae, $34.9 \%$ exhibited cartilage erosion in condylar margins, 5.6\% exhibited subchondral bone exposure in condylar margins, $19.4 \%$ had thickened capsules (Table 2), $2.7 \%$ had long digital extensor tendon injuries associated with lateral luxation, $9.3 \%$ had ruptured cranial cruciate ligaments, and $3.1 \%$ exhibited prolapse of the menisci. Synovitis occurred in $37.5 \%$ of the animals with Grade I luxation. Periarticular osteophytes and shallow trochlear grooves were most frequently found among the animals with Grade II or III luxation. Erosion of the femoral condylar margins and thickened capsules occurred most frequently among those with Grade III luxation, while absent trochlear grooves were most frequent among those with Grade IV luxation. Exposure of subchondral bone on the condylar margins predominated among those with Grade III or IV luxation. Lesions in medial condyles were observed in joints in medial luxation, whereas lesions in lateral condyles were frequent in joints in lateral luxation. Extra-patellar lesions were proportionally higher among those weighing over $15 \mathrm{~kg}$.

The frequency of extra-patellar articular lesions according to age, body weight, and degree of luxation is presented in Table 2. 
Table 2. Estimated extra-patellar articular lesions in dogs with patellar luxation treated at the Veterinary Hospital, UFMG, 2000-2010 according to degree of luxation, body weight, and age

\begin{tabular}{|c|c|c|c|c|c|c|c|c|c|c|c|c|c|c|c|}
\hline \multicolumn{16}{|c|}{ Extra-patellar articular lesions } \\
\hline \multicolumn{3}{|c|}{ Synovitis } & \multicolumn{2}{|c|}{ Osteophytes } & \multicolumn{2}{|c|}{$\begin{array}{l}\text { Shallow } \\
\text { trochlea }\end{array}$} & \multicolumn{2}{|c|}{$\begin{array}{l}\text { Absent } \\
\text { trochlea }\end{array}$} & \multicolumn{2}{|c|}{$\begin{array}{l}\text { Femoral } \\
\text { condyle erosion }\end{array}$} & \multicolumn{2}{|c|}{$\begin{array}{l}\text { Thickened } \\
\text { capsule }\end{array}$} & \multicolumn{2}{|c|}{$\begin{array}{l}\text { Subchondral } \\
\text { bone exposure }\end{array}$} & \multirow{2}{*}{$\begin{array}{l}\begin{array}{l}\text { Assessed } \\
\text { joints }\end{array} \\
\mathbf{n}^{\circ}\end{array}$} \\
\hline Severity & $\mathbf{n}^{\circ}$ & $\%$ & $\mathbf{n}^{\circ}$ & $\%$ & $\mathbf{n}^{\circ}$ & $\%$ & $\mathbf{n}^{\circ}$ & $\%$ & $\mathbf{n}^{\circ}$ & $\%$ & $\mathbf{n}^{\circ}$ & $\%$ & $\mathbf{n}^{\circ}$ & $\%$ & \\
\hline Grade I & 6 & 37.5 & 1 & 6.25 & 0 & 0 & 0 & 0 & 0 & 0 & 0 & 0 & 0 & 0 & 16 \\
\hline Grade II & 34 & 31.2 & 37 & 33.9 & 51 & 46.8 & 4 & 3.7 & 37 & 33.9 & 21 & 19.3 & 4 & 3.7 & 109 \\
\hline Grade III & 14 & 28.6 & 16 & 32,7 & 23 & 46.9 & 3 & 6.1 & 29 & 59.2 & 13 & 26.6 & 6 & 12.2 & 49 \\
\hline Grade IV & 9 & 11.5 & 11 & 14.1 & 32 & 41.0 & 26 & 33.3 & 22 & 28.2 & 15 & 19.2 & 9 & 11.5 & 78 \\
\hline Total & 63 & & 65 & & 106 & & 33 & & 88 & & 49 & & 19 & & 252 \\
\hline Weight & & & & & & & & & & & & & & & $\begin{array}{l}\text { Assessed } \\
\operatorname{dogs}\left(n^{\circ}\right)\end{array}$ \\
\hline$<5 \mathrm{~kg}$ & 18 & 17.5 & 20 & 19.4 & 37 & 35.9 & 17 & 16.5 & 23 & 22.3 & 13 & 12.6 & 2 & 1.9 & 103 \\
\hline $5-15 \mathrm{~kg}$ & 15 & 34.1 & 15 & 34.1 & 22 & 50.0 & 3 & 6.8 & 15 & 34.1 & 6 & 13.6 & 5 & 11.4 & 44 \\
\hline$>15 \mathrm{~kg}$ & 11 & 39.3 & 17 & 60.7 & 13 & 46.4 & 1 & 3.6 & 27 & 96.4 & 13 & 46.4 & 6 & 21.4 & 28 \\
\hline Total & 44 & & 52 & & 72 & & 21 & & 65 & & 32 & & 13 & & 175 \\
\hline Age & & & & & & & & & & & & & & & $\mathrm{n}^{\mathrm{o}}$ \\
\hline$<12$ months & 9 & 10.9 & 6 & 7.3 & 40 & 48.8 & 18 & 21.9 & 15 & 18.3 & 13 & 15.8 & 5 & 6.1 & 82 \\
\hline $\begin{array}{l}12-24 \\
\text { months }\end{array}$ & 7 & 38,9 & 3 & 16,6 & 4 & 22,2 & 1 & 5,5 & 5 & 27,8 & 4 & 22,2 & 0 & 0 & 18 \\
\hline$>24$ months & 26 & 32.1 & 41 & 50.6 & 32 & 39.5 & 3 & 3.7 & 30 & 37.0 & 15 & 18.5 & 8 & 9.9 & 81 \\
\hline
\end{tabular}

Patellar reluxation after surgical repair occurred in $13.5 \%$ of the joints, and this was distributed across all grades, ranging between $6 \%$ and $15 \%$. Statistical analysis using the chi-square test suggests that no statistically significant differences exist between the variable "reluxation patellar" and "degree of luxation," "type of luxation (medial or lateral)," and "body weight" $(\mathrm{P}>0.05)$.

The frequency of reluxation according to body weight, type, and degree of luxation is shown.

Table 3. Estimated patellar reluxation in dogs treated at the Veterinary Hospital, FUMG, 2000-2010 according to the type (medial or lateral) of luxation, degree of luxation, and body weight. The rate of patellar reluxation was assessed using the chi-square test

\begin{tabular}{clcc}
\hline Severity & $\mathrm{n}$ & Reluxation $(\%)$ & NO reluxation $(\%)$ \\
\hline Grade I & 16 & $1(6.2)^{\mathrm{a}}$ & $5(93.8)^{\mathrm{a}}$ \\
Grade II & 106 & $14(13.2)^{\mathrm{a}}$ & $95(87.2)^{\mathrm{a}}$ \\
Grade III & 49 & $7(14.3)^{\mathrm{a}}$ & $42(85.7)^{\mathrm{a}}$ \\
Grade IV & 78 & $12(15.4)^{\mathrm{a}}$ & $66(84.6)^{\mathrm{a}}$ \\
\hline Total & 252 & $34(13.5)$ & $218(86.5)$ \\
\hline Medial luxation & 218 & $30(13.8)^{\mathrm{a}}$ & $188(86.2)^{\mathrm{a}}$ \\
Lateral luxation & 34 & $4(11.8)^{\mathrm{a}}$ & $30(88.2)^{\mathrm{a}}$ \\
\hline
\end{tabular}

In the columns, frequencies with different letters differ between groups using the chi-square test $(P<0.05)$.

\section{DISCUSSION}

In the literature, there are few descriptions of lesions occurring in the stifle joints of dogs with patellar luxation. Cartilage erosion on the patellar articular surface was reported by Remédios et al. (1992); however, they did not provide information about the extent of the erosion or the weight, age, or degree of luxation. Daems et al. (2009) report cartilage erosions mainly in heavier dogs and with Grade IV patellar luxation.

The results of this study indicate a high frequency of patellar and extra-patellar lesions, especially in Grades II and III luxation. According to the literature, although these animals exhibit intermittent and persistent lameness, respectively (Roush, 1993; Vasseur, 2003; Piermattei, 2006) they continue to use the affected limb for ambulation. These facts 
account for the larger number of lesions found among animals with Grade II or III luxation. The use the affected limb leads to joint wear. This is different from animals with Grade IV luxation, who do not bear their weight on the affected limb, but drag or carry it while the weight is transferred to the front limbs.

Roy et al. (1992) did not find a significant association between the degree of luxation and the progression of radiological articular changes, which suggests that some of the alterations that are visible during surgery might not be detectable in radiological exams.

Because of the anatomy and biomechanics of the member, the friction between the articular surfaces of the patella and femoral trochlea will cause erosion of the medial femoral condyle and lateral patellar surface in medial luxation and of the lateral femoral condyle and medial patellar surface in lateral luxation.

Erosion of the articular surfaces is a result of friction between the patella and the condylar edge, causing wear on both the patella and the condyle. The quadriceps mechanism is responsible for the extension member, and a healthy patellofemoral joint is essential for implementation of this function. The patellofemoral joint greatly increases the efficiency of the quadriceps mechanism and facilitates extension. The quadriceps extensor mechanism consists of the quadriceps, patella, trochlea, patellar tendon, and tibial tuberosity. These structures must be aligned. Abnormal alignment of the extensor mechanism reduces the extensor moment of the stifle (McKee and Cook, 2006).

Misalignment of the quadriceps leads the kneecap to become dislocated and press and brush on the lateral or medial condyle surface during limb movement. Erosion is observed in dislocations when the quadriceps' extension function is maintained. In these cases, the pressure of the quadriceps extensor during movement, acting on an improper surface for receiving the force, causes wear injuries. The injury is more severe in animals weighing more than $15 \mathrm{~kg}$. The greater frequency of lesions in Grades II and III luxation can be explained by moderate functional changes that allow member extension, promoting compression between the patella and condyle edge. In Grade IV luxation, there is a serious decreased range of extension in the joint associated with contracture of the soft tissues caudal to the joint (Denny and Butterworth, 2006) which prevents the friction pressure between the condyle and patellar edge. Patellar luxation is also responsible for the resulting absence of a trochlear groove.

In this study, the frequency and severity of articular lesions were higher among the animals weighing at least $15 \mathrm{~kg}$, as Daems et al. (2009) observed. This finding might be attributed to the biomechanical instability resulting from the greater load to which the stifle joint is subjected. Biomechanical stability is considered to be essential for an appropriate supply of blood to the articular cartilage (L'Eplattenier and Montavon, 2002) because inadequate nutrition results in joint degeneration, which is observed in cases of patellar luxation.

The high frequency of patellar lesions among animals aged more than 24 months might be the result of disease duration. As some authors have observed (Remedios et al., 1992; Hayes et al., 1994; Gibbons et al., 2006; Piermattei et al., 2006), patellar luxation mainly affects young animals still in the growing phase, and they are often not referred for treatment for several reasons, among which, the lack of symptoms or the presence of merely mild clinical signs, stands out. Consequently, alterations of the patella resulting from chronic friction have already appeared by the time surgery is performed.

The reluxation rate observed in this study $(13.5 \%)$ is within the range reported by Arturs and Langlay-Hobbs (2006) and Wandgee (2013), although up to $50 \%$ has been reported (Pérez, 2014). Arthurs and Langley-Hobbs (2006) report greater frequency of major and patellar reluxation complications in dogs weighing $20 \mathrm{~kg}$ or more, compared to smaller dogs. The opposite was observed in this study; there were two reluxations among the 46 dogs who weighed more than $20 \mathrm{~kg}$. Our results did not indicate a significant association between body weight and reluxation.

Recurrence of patellar luxation is a common complication associated with surgery, and among the factors that contribute to redislocation are the severity of the lesions, because Grade III and IV 
luxations indicate poor shaft alignment; failure to align the tuberosity of the tibia with trochlea; and contracture of soft tissues caudal to the joint, affecting the joint range of motion postoperatively (McKee and Cook, 2006). As with the loss of convexity of the patella, it loses its slot in the femoral trochlea. Daems et al. (2009) postulate that one of the reasons for surgical failure in stable post-surgical patellas is the presence of cartilage erosion. Mostafa et al. (2008) proposed that the proximodistal malalignment of the patella (patella alta and baja) influenced reluxation. Patella alta is defined as the proximal displacement of the patella within the femoral trochlear groove. It has been speculated that patella alta may play a role in canine patellar luxation (Johnson et al., 2002; Johnson et al., 2006). The position of the patella in the trochlea, as Mostafa et al. (2008) observed, might be the reason for one case of patellar reluxation in our study. One dog, weighing more than $20 \mathrm{~kg}$ with recurrent Grade II bilateral medial luxation, was evaluated. To assess the patellar position on the femoral trochlea, radiographic evaluation was performed according to the method described by Mostafa et al. (2008). After osteotomy of the tibial tuberosity, as described by Johnson et al. (2006) and distally transposing $0.5 \mathrm{~cm}$ the tibial tubercle, the patella remained in the groove.

We found no instance of implant failure among animals weighing at least $15 \mathrm{~kg}$ because the implants used were compatible with the dogs' weights.

Postoperative measures, such as activity restriction and physical therapy, contribute to the success of treatment and might prevent some postoperative complications and favor an early recovery of the muscle mass and the functional performance of the limb.

Based on these results, we conclude that patellar luxation should be subjected to surgical repair even when the clinical signs of disease are mild or absent, because this condition triggers patellar and extra-patellar changes that result in a more difficult surgery and promote the progression of joint degeneration, thus reducing the odds of a full and painless recovery of joint function.

\section{REFERENCES}

ARTHURS, G.I.; LANGLEY-HOBBS, S.J. Complications associated with corrective surgery for patellar luxation in 109 dogs. Vet. Surg. v.35, p.559-566, 2006.

DAEMS, R.; JANSSENS, L.A.; BÉOSIER, Y.M. Grossly apparent cartilage erosion of the patellar articular surface in dogs with congenital medial patellar luxation. Vet. Comp. Orthop. Traumatol., v.22, p.222-224, 2009.

DENNY, H.R.; BUTTERWORTH, S.T. The stifle. In: A guide to canine and feline orthopaedic surgery. 4.ed. Iowa: Blackwell Publishing, 2006. 512-553p.

GIBBONS, S.E.; MACIAS, C.; TONZING, M.A. et al. Patellar luxations in 70 large breed dogs. J. Small Anim. Pract., v.47, p.3-9, 2006.

HAYES, A.G.; BOUDRIEAU, R.J.; HUNGERFORD, L.L. Frequency and distribution of medial and lateral patellar luxation in dogs: 124 cases (1982-1992). J. Am. Vet. Med. Assoc., v.57, p.105-109, 1994.

JOHNSON, A.L.; BROADDUS, K.D.; HAUPTMAN, J.G. et al. Vertical patellar position in large-breed dogs with clinically normal stifle and large-breed dogs with medial patellar luxation. Vet. Surg., v.35, p.78-81, 2006.

JOHNSON, A.L.; PROBST, C.W.; DECAMP, C.E. et al. Vertical position of the patella in the stifle joint of the clinically normal large-breed dogs. Am. J. Vet. Res., v.63, p.42-46, 2002.

L'EPLATTENIER, H.; MONTAVON, P. Patellar luxation in dogs and cats: Pathogenesis and diagnosis. Small Anim. Exotics, v.24, p.234240, 2002.

MCKEE, M.W.; COOK, J.L. The stifle. In: HOULTON, J.E.F.; COOK, J.L.; INNES, J.F.; LANGLEY-HOBBS, S.J. (Eds.). BSAVA manual of canine and feline musculoskeletal disorders. ]Gloucestershire]: BSAVA, 2006. p.350-374.

MOSTAFA, A.A.; GRIFFON, D.J.; THOMAS, M.W. et al. Proximodistal alignment of the canine patella: radiographic evaluation and association with medial and lateral patellar luxation. Vet. Surg., v.31, p.201-211, 2008. 
PÉREZ, P.; CHELSEA, W.T.; LAFUENTE, P. Management of medial patellar luxation in dogs: what you need to know. Vet. Ireland J., v.4, p.636-640, 2014.

PIERMATTEI, D.L.; FLO, G.L.; DECAMP, C.E. The stifle joint. In: Handbook of small animal orthopedics and fracture repair. 4.ed. Philadelphia: Saunders, 2006. p.562-632.

PUTNAM, R.W. Patellar luxation in the dog. 1968. Dissertation (Mestrado) - University of Guelph, Ontario, CA.

REMEDIOS, A.M.; BASHER, A.W.P.; RUNYON, C.L. et al. Medial patellar luxation in 16 large dogs: a retrospective study. Vet. Surg., v.21, p.5-9, 1992.

ROUSH, J.K. Canine patellar luxation. Vet. Clin. N. Am. Small Anim. Pract., v.23, p.855-868, 1993.

ROY, R.G.; WALLACE, L.J.; JOHNSTON, G.R. et al. A retrospective evaluation of stifle osteoarthritis in dogs with bilateral medial patellar luxation and unilateral surgical repair. Vet. Surg., v.21, p.475-479, 1992.
SINGLETON, W.B. The surgical correction of stifle deformities in the dog. J. Small Anim. Pract., v.10, p.59-69, 1969.

SOUZA, M.M.D.; RAHAL, S.C.; PADOVANI, C.R. et al. Estudo retrospectivo de cães com luxação patelar medial tratados cirurgicamente [retrospective study of dogs with surgically treated medial patellar luxation]. Cienc. Rural, v.40, p.31-36, 2010.

VASSEUR, P.B. Stifle joint. In: SLATTER, D. (Ed.). Textbook of small animal surgery. 3.ed. Philadelphia: Saunders, 2003. p.2090-2133.

WANDGEE, C. Evaluation of surgical treatment of medial patellar luxation in Pomeranian dogs. Vet. Comp. Orthop. Traum., v.26, p.435-439, 2013. 